Mamba'ul 'Ulum, Vol. 15, No. 2, Oktober 2019: 225-233

\title{
PERAN PENGHULU DALAM PELAYANAN PERNIKAHAN POLIGAMI BAGIWARGA NEGARA ASING (Analisis Terhadap Sinkronisasi Peraturan Tentang Izin Poligami)
}

\author{
Zainal Abidin
}

Institut Islam Mamba’ul 'Ulum Surakarta

\begin{abstract}
Abstrak: Poligami adalah perkawinan seorang suami dengan lebih dari seorang istri dalam waktu yang bersamaa. Lawan poligami adalah monogami. Dalam perspektif hokum Islam, poligami di batasi sampai maksimal empat orang istri. Poligami sudah berjalan seiring perjalanan sejarah umat manusia, sehingga poligami bukanlah suatu trend baru yag muncul tiba-tiba saja. Dalam peraturan perundang-undangan tentang perkawinan di Indonesia menjamin seseorang yang akan melaksanakan poligami dengan syarat terpenuhi dan tidak dalam larangan agamanya. Permasalahan poligami muncul ketika peraturan Menteri agama no, 19 tahun 2018 tentang pencatatan perkawinan dalam pasal 24 dan 25 mengatur tentang izin poligami bagi warga negara asing di pengadilan agama. Metode yang digunakan dalam penelitian makalah ini adalah metode peneltian hukum normatif yang bertujuan untuk menganalisis dan mencari solusi terhadap sinkronisasi vertikal antara peraturan perundang-undangan dengan tingkatan yang berbeda yang mengatur masalah yangsama, yaitu tentang izin poligami bagi Warga Negara Asing,sudah serasi apakah ada konflik dengan peraturan perundangundangan yang lebih tinggi.
\end{abstract}

Kata kunci: penghulu, izin poligami, warga negara asing, sinkronisasi vertikal

\section{PENDAHULUAN}

Dewasa ini wacana mengenai poligami kembali menjadi issu sentral di setiap kondisi,waktu, dan tempat. Tidaksaja pada lingkup akademisi, majlis taklim, pondok pesantren, kultum di masjid-masjid dn musholla, tetapi juga di warung-warung kopi, pangkalan ojek, ataupun kerumunan ibu-ibu dan bapak-bapak. Kasus poligami da'i selebritis kondang KH Abdullah Gymnastiar yang terkenal dengan sebutan 'A'a Gym telah menguak kembali polemik tentang eksistensi poligami. Masalah menjadi semkin panas lgi (walaupun tiada kaitan langsung) ketika terjadi peristiwa poligami antara Yahya Zaini sebagai wakil rakyat dan Maria Eva.

Ramainya pesan pendek melalui SMS kepada Presiden Susilo Bambang Yudhoyono (SBY) pada waktu itu, membuat orang nomor satu di Idonesia serta merta mengadakan sidang singkat dengan para pembantunya antara lain Menteri AgamaMenteri Pemberdayaan Peremuan dan menteri-menteri lain yang mengikat. Isi dari sidang singkat tersebut berupa peninjauan kembali UU No. 1 Tahun 1974 tentang Perkawinan beserta dua peraturan pemerintah sebagai operasionalisasi dari UU No. 1 Tahun 1974 tersebut,yaitu PP No. 9 Tahun 1975 tentang Pelaksanaan UU No. 1 Tahun 1974 tentang Perkawinan dan PP No. 10 tahun 1983 Jo. PP No. 45 Tahun 1990 tentangIzin Perkawinan dan Perceraian bagi Pegawai Negeri Sipil. Khusus PP No. 10 Tahun 1983 ini sebelumnya oleh Presiden Abdurrahman Wahid (Gus Dur) telah dicabut, karena "mempersulit keberadaan PNS laki-laki untuk melakukan poligami". Sebagai issu selanjutnya adalah memperluas muatan Peraturan Pemerintah tentang PerizinanPerkawinan dan Perceraian tidak saja bagi PNS/TNI/Polri tetapi 
juga berlaku untuk masyarakat luas. Dengan kata lain pemerintah memberikan "peraturan ketat" bagi seorang suami yang akan melakukan poligami.

Berdasarkan paparan kasus tersebut di atas apakah sebenarnya dibalik praktek poligami itu?Bukankah peraturan perundang undangan mengaturnya dengan jelas?Apakah praktek poligami selama ini telah menimbulkan permasalahan serius sehingga pemerintah harus ikut menyibukkan diri dalam masalah ibadah ummat? Bukankah sebelumnya sudah banyak terjadi praktek poligami dilakukan oleh public figure seperti mantan Wakil Presiden Hamzah Haz, dai sejuta ummat Zainuddin MZ, sang Raja Dangdut Rhoma Irama dan masih banyak lagi. ${ }^{1}$

Terkait dengan kontek pembahasan makalah ini, beberapa bulan yang lalu muncul suatu masalah yang sangat serius yang sempat merisaukan dan membingungkan serta timbul beberapa pertanyaan dari sebagian Penghulu di Kabupaten Klaten, yaitu tentang pernikahan poligami bagi Warga Negara Asing (WNA) yang akan dilaksanakan di Indonesia. Hal tersebut merupakan masalah baru dan aktual yang perlu diberikan solusi dalam pelayanan pernikahan poligami yang dinyatakan dalam Peraturan Menteri Agama No. 19 Tahun 2018 tentang Pencatatan Perkawinan. Dalam Pasal 24 huruf c, salah satu persyaratan perkawinan campuran bagi warga negara asing: "izin poligami dari Pengadilan Agama atau instansi berwenang. Pada negara asal calon pengantin bagi suami yang hendak beristeri lebih dari seorang", dan Pasal 25 ayat (2) huruf c: "izin poligami dari Pengadilan Agama di Indonesia bagi warga Negara asing yang akan beroligami.",

\section{PEMBAHASAN}

\section{Analisis Terhadap Izin Poligami Bagi Warga Negara Asing}

Pernikahan lebih dari seorang isteri dalam waktu yang berbeda atau poligami telah berjalan sejak lama sesuai dengan perkembangan manusia dalam beriteraksi antara manusia satu dengan lainnya baik dalam lingkup satu negara maupun dengan negara lainnya. Disamping itu praktek poligami tersbut mendapat legalitas baik dari segi agama maupun hukum kebiasaan di negara masing-masing. Bagi warga negara Indonesia, yang akan melaksankan poligami telah ada peraturan perundang-undangan yang mengatur dengan mengajukan permohonan ijin poligami di Pengadilan Agama.

Beberapa bulan yang lalu di wilayah KUA Kecamatan Wedi Kabupaten Klaten ada seorang calon pengantin seorang laki-laki Warga Negara Asing (WNA) yang akan melaksanakan pernikahan poligami. Hal tersebut akan menambah resah para Penghulu dalam pelayanan nikah, bagaimanapun seorang Penghulu tetap menjalankan tugas dan fugsinya dan tidak boleh lepas tangan dari tanggung jawabnya. Peraturan Menteri Agama Nomor: 19 Tahun 2018 Tentang Pencatatan Perkawinan, dalam Pasal 24 dan 25 mengatur tentang izin poligami bagi warga negara asing di Pengadilan Agama. Hal tersebut menimbulkan permasalahan baikperan bagi Penghulu maupun para hakim di Pengadilan Agama. Mencoba komunikasi dengan beberapa hakim di Pengadilan Agama belum mendapat informasi

${ }^{1}$ Titik Triwulan Tutik, S. H, M. H dan Trianto, S. Pd, M. Pd, Poligami Perspektif Perikatan Nikah, Telaah Kontekstual Menurut Hukum Islam dan Undang-undang Perkawinan No. 1 Tahun 1974, Prestasi Pestaka, Jakarta, 2007, Cet. 1, hal. 3.

${ }^{2}$ Peraturan Menteri Agama No. 19 Tahun 2018 tentang Pecatatan Perkawinan, Kementerian Agama, Jakarta, Berita Negara RI Tahun 2018 Nomor 1153, 27 Agustus 2018. 
tersebut. Mencoba bertanya lebih jauh, seandainya ada permohonan izin poligami, akan menambah masalah dari segi bahasa juga harus melibatkan lembaga bantuan hukum yang bersifat internasional.

Selain itu Peraturan Menteri Agama No. 19 Tahun 2018 tersebut tidak ada sinkronisasi dengan peraturan perundang-undangan yang lebih tinggi yang mengatur materi yang sama. Karena sudah terjadi konflik dengan aturan diatasnya maka harus diserasikan dengan mengadakan analisis dari segi sinkronisasi baik vertikal dan horizontal.

\section{ANALISIS MASALAH}

\section{Analisis Terhadap Sikronisasi Peraturan Tentang Izin Poligami Bagi Warga Negara Asing}

Dalam bab ini penulis akan melakukan analisis terhadap peraturan tentang izin pernikahan poligami, khususnya bagi warga negara asing. Mengingat data yang digunakan penulis dalam melakukan analisis diperoleh dari bahan-bahan pustaka, berupa bahan hukum primer seperti Undang-undang Dasar, Ketetapan MPR, Peraturan Perundang-undangan, dan lain-lainnya, berupa bahan hukum sekunder seperti hasil-hasil penelitian dan karya-karya dari para ahli hukum di bidang yang bersangkutan, serta bahan hukum tersier lainnya seperti: kamus, ensiklopedia, dan lain-lainnya, maka metode penelitian yang tepat untuk maksud tersebut ialah metode penelitian hukum normatif. Penelitian hukum normatif ini mencakup berbagai penelitian, yaitu penelitian terhadap asas-asas hukum, penelitian terhadap sistematika hukum, penelitian terhadap taraf sinkronisasi vertikal dan horizontal, perbandingan hukum, dan sejarah hukum. ${ }^{3}$

Dari berbgai jenis penelitian hukum normatif tersebut di atas tidak akan dilakukan penelitian semuanya, akan tetapi hanya yang berkaitan pokok pembahasan, yakni tentang analisis terhadap taraf sinkronisasi vertikal dan horizontal tentang peraturan izin poligami bagi warga negara asing. Penelitian dan analisis yang demikian ini bertujuan untuk mengungkapkan kenyataan sampai sejauh manakah suatu perundang-undangan tertentu itu serasi secara vertikal atau serasi secara horisontal, apabila perundang-undangan tersebut adalah sederajat dan termasuk bidang yang sama. Apabila yang dilakukan adalah analisis terhadap taraf sinkronisasi vertikal, maka yang termasuk dalam ruang lingkupnya adalah berbagai perundang-undangan yang derajatnya berbeda-beda yang mengatur bidang yang sama. Untuk dapat melakukan pembahasan taraf sinkronisasi, lebih dahulu harus dilakukan inventarisasi perundang-undangan yang mengatur bidang hukum yang telah ditentukan untuk dianalisis. ${ }^{4}$ Inventarisasi perundang-undangan tersebut harus disusun menurut urut-urutan hirarki perundang-undangan. Berdasarkan Ketetapan MPR No.III Tahun 2000 tentang Sumber Hukum Dan Tata Urutan Peraturan Perundang-undangan, dalam Pasal 2 dinyatakan: "Tata urutan peraturan perundang-undangan merupakan pedoman dalam pembuatan aturan hukum dibawahnya. Tata urutan tersebut adalah sebagai berikut:

1. Undang-Undang Dasar 1945;

2. Ketetapan Majelis Permusyawaratan Rakyat Republik Indonesia;

${ }^{3}$ Soerjono Soekanto dan Sri Mamudji, Penelitian Hukum Normatif, Rajawali, Jakarta,1985, hal. 15,

${ }^{4}$ Ronny Hanitijo Soemitro, Metodologi Penelitian Hukum Dan Jurimetri, Ghalia Indonesia, Jakarta,1988,Cet. 3, hal 26-27. 
3. Peraturan Pemerintah Pengganti Undang-undang (Perpu);

4. Peraturan Pemerintah;

5. Keputusan Presiden Yang Bersifat Mengatur;

6. Peraturan Daerah. ${ }^{5}$

Berkaitan dengan pembahasan tentang izin poligami bagi warga negara asing dapat diinventrisasi dari peraturan yang terkait sebagaiberikut: Pertama, UU No. 1 Tahun 1974 tentang Perkawinan, Pasal 4 ayat (2) hanya mengatur alasan izin poligami, dan Pasal 5 ayat (1) mengatur syarat-syarat mengajukan permohonan izin poligami bagi Warga Negara Indonesia (WNI). Kedua, PP No. 9 Tahun 1975 Tentang Peraturan PelaksanaanUU No.1 Tahun 1974 Tentang Perkawinan, Pasal 40, 41 a, b,c, d, 42 ayat (1) dann (2) dan 43, mengatur tentang prosedur poligami bagi Warga Negara Indonesia (WNI). ${ }^{6}$ Ketiga, Inpres No. 1 Tahun 1991 Tentang Kompilasi Hukum Islam, dalam Bab IX Pasal 55 sampai dengan Pasal 59 bersifat mempertegas dari Bab VIII Peraturan Pemerintah No. 9 Tahun 1975 tentang prosedur izin poligami bagi Warga Negara Indonesia (WNI). Keempat, sementara dalam Peraturan Menteri Agama No. 19 Tahun 2018 Tentang Pencatatan Perkawinan, dimana Pasal 24 dan 25 mengatur tentang izin poligami bagi Warga Negara Asing (WNA). Dari inventarisasi tersebut di atas dapat diketahui bahwa peraturan yang mengatur tentanag izin poigami bagi Warga Negara Asing (WNA) dalam Peraturan Menteri Agama No. 19 Tahun 2018 dalam Pasal 24 dan 25 setelah dianalisis tidak ada sinkronisasi dan bertentangan dengan peraturan perundang-undangan di atasnya.

Berkaitan dengan pembahasan di atas dalam Pasal 4 Tap MPR No. III Tahun 2000 Tentang Sumber Hukum dan Tata Urutan Peraturan Perundang- undangan, menyatakan:

(1) Sesuai dengan Tata Urutan Peraturan Perundang-undangan ini, maka setiap aturanhukum yang lebih rendah tidak boleh bertentangan dengan aturan hukum yang lebih tinggi.

(2) Peraturan atau Keputusan Mahkamah Agung, Badan Pemeriksa Keuangan, Menteri, Bank Indonesia, Badan atau Komisi yang setingkat yang dibentuk oleh Pemerintah tidak boleh bertentangan dengan ketentuan yang termuat dalam Tata Urutan Peraturan Perundang-undangan ini. ${ }^{7}$

Secara materiil pencantuman Pasal 24 dan 25 Peraturan Menteri Agama No. 19 Tahun 2018 Tentang Pencatatan Perkawinan yang mengatur tentang izin poligami bagi Warga Negara Asing, bertentangan dengan perundang-undangn yang lebih tinggi, yakni UU No. 1 Tahun 1974 tentang Perkawinan dan PP No. 9 Tahun 1975, dimana keduanya tidak mengatur tentang izin poligami bagi Warga Negara Asing. Dalam hal ini dapat disandarkan pada asas hukum, "kalau terjadi konflik antara peraturan perundang-undangan yang tinggi dengan yang rendah maka yang tinggilah yang harus didahulukan" (Lex superior derograt legi inferiori). ${ }^{8}$

Bagir Manan, mengemukakan, dasar Pembentukan Peraturan Menteri, bahwa: Menteriadalah pejabat administrasi negara yang menjalankan fungsi pemerintahn di bidang

${ }^{5}$ Ketetapan MPR No. III Tahun 2000 Tentang Sumber Hukum dan Tata Urutan PeraturanPerundangundangan, Surabaya, Arkola, 2005, Cet. 1, hal. 139.

${ }^{6}$ Ahmad Rofiq, Hukum Perdata Islam di Indonesia, Rajawali Pers, Jakarta, 2013, Cet. 1, hal. 142.

${ }^{7}$ Tap MPR No. III Tahun 2000, Arkola, Surabaya, Cet. 1, 2005, hal. 141. hal. 7 .

${ }^{8}$ Sudikno Mertokusumo, Penemuan Hukum Sebuah Pengantar, Liberty, Yogyakarta, 2001, Cet. 2, 
tertentu. Berbagai aturan administrasi diperlukan untuk melaksanakan tugasnya baik berupa peraturan biasa ataupun aturan kebijakan. Menteri hanya boleh membuat atauran dalam bidang tugas kementeriannya. Peraturan di luar tugas kementeriannya, dianggap sebagai tindakan melampaui wewenang (detournement de pouvoir). Peraturan Menteri merupakan peraturan perundang-undangan terendah dari pemerintah pusat. Pejabat pemerintahan di bawah menteri tidak berwenang membuat peraturan (berlaku umum). ${ }^{9}$

Maria Farida, menjelasakan bahwa: fungsi dari Peraturan atau Keputusan Menteri adalah: a. Menyelenggarakan pengaturan secara umum dalam rangka penyelenggaraan kekuasaan pemerintahan di bidangnya, b. Menyelenggarakan pegaturan lebih lanjut ketentuan dalam Keputusan Presiden, c. Menyelenggarakan pengaturan lebih lanjut ketentuan dalam undang-undang yang tegas-tegas menyebutnya, d. Menyelenggarakan pengaturan lebih lanjut ketetntuan dalam Peraturan Pemerintah yang tegas-tegas menyebutnya. ${ }^{10}$

Dalam hal ini A. Hamid S. Attamimi, menjelaskan bahwa: "Mengingat kedudukan menteri menurut Undang-Undang Dasar 1945 merupakan Pembantu Presiden dan tidak bertanggung jawab kepada DPR, maka segala kewenangan menteri semestinya berasal dari kewenangan Presiden, sehingga kewenangan menteri dibidang pemebentukan peraturan perundang-undangan juga semestinya berasal dari kewenangan Presiden. Dengan demikian maka, suatu undang-undang sebenarnya tidak seyogyanya menetapkan suatu hal diatur dengan Keputusan menteri, oleh karena menteri adalah Pembantu Presiden. Namun dalam praktek hal itu sering terjadi dengan alasan keluwesan; akan tetapi apakah keluwesan yang tidak terbatas malahan akan menimbulkan kesewenang-wenangan? Inilah gunanya penelitian terhadap taraf sinkronisasi perundang-undangan secara vertikal dan horizontal yang sangat dibutuhkan di Indonesia demi kepastian dan kesebandingan hukum yang serasi sehingga menumbuhkan keadilan hukum. ${ }^{11}$

Soehino, dalam penjelasannya berdasarkan suatu ketentuan dalam undang-undang, suatu wewenang baik untuk mengatur sesuatu maupun untukmelaksanakan sesuatu dapat didelegasikan kepada suatu peraturanperundangan yang lebih rendah tingkatnya atau kepada pejabat tertentu. Dengan demikian ada dua macam delegasi wewenang, yaitu delegasi wewenang untuk membuat peraturan perundangan, ini adalah suatu penyerahan wewenang untuk mengatur sesuatu hal oleh undang-undang kepada peraturan perundangannya yang tingkatannya lebih rendah, delegasi wewenang ini adalah delegasi wewenang yang bersifat mengatur; dan delegasi wewenang untuk melaksanakan sesuatu, ini adalah suatu penyerahan wewenang untuk melaksanakan sesuatu hal oleh undang-undang kepada pejabat tertentu, delegasi ini adalah delegasi wewenang yang bersifat melaksanakan.

Namun, pendelegasian wewenang oleh undang-undang baik yang bersifat mengatur maupun yang bersifat melaksanakan, harus memperhatikan hal-hal sebagai berikut: Dalam pendelegsian wewenang yang bersifat mengatur harus ditentukan dengan tegas hal atau hal-

${ }^{9}$ Bagir Manan, Teori dan Politik Konstitusi, Dirjen Dikti Depdiknas, Jakarta, 2000, hal. 146.

${ }^{10}$ Maria Farida Indrati Soeprapto, Ilmu Perundang-Undangan Dasar-Dasar dan Pembentukannya, Kanisius, Yogyakarta, 1998, hal. 117-118.

${ }^{11}$ A. Hamid S. Attamimi, Peranan Keputusan Presiden RI Dalam Penyelenggaraan Negara, Suatu Studi Analisis Mengenai Keputusan Presiden Yang Berfungsi Pengaturan Dalam Kurun Waktu Pelita I-IV, Fakultas Pascasarjana UI, Jakarta, 1982, hal. 71. 
hal apa yang didelegasikan wewenang pengaturannya dan jenis peraturan perundangan yang ditugaskan untuk mengatur masing-masing hal tersebut. Delegasi wewenang yang bersifat mengatur yang tidak menentukandengan tegas jenis peraturan perundangan yang mana yang ditugaskan untuk mengatur hal itu, dapat menimbulkan ketidakpastian.

Sedangkan dalam delegasi wewenang yang bersifat melaksanakan harus ditentukan dengan tegas hal atau hal-hal apa yang harus dilakukan dan pejabat mana yang ditugaskan untuk melakukan kewenangan itu. ${ }^{12}$

\section{Hukum Perdata Internsional dan Pernikahan Poligami Warga Negara Asing}

Bahwa suatu perkawinan yang dicatatkan di KUA Kecamatan disamping terkait masalah ibadah juga berhubungan dengan keperdataan seseorang. Pernikahan poligami bagi warga negara asing yang dilaksanakan di Indonesia terkait erat dengan masalah hukum perdata internasional. Hukum perdata merupakan subsistem dari system hukum yang berlaku dalam sebuah negara. Ketentuan-ketentuannya mengatur tentang hubungan hokum perorangan dalam usaha memenuhi kebutuhan individunya, maka hukum perdata itu merupakan hukum nasional negara. Suatu hubungan hukum dapat terjadi dan menyangkut dua individu atau lebih dalam bidang keperdataan dan melibatkan unsur asing di dalam hubungan hukum perdata itu. Hal itu dapat menimbulkan masalah yang memerlukan penyelesaian secara internasional. Perkataan "internsional" dapat diartikan antar bagsabangsa dari pelbagai negara.

Dalam kaitannya dengan hukum perdata, arti antarbagsa-bagsa merupakan kompleksitas peraturan hukum perdata yang dibawa dari masing-masing negara dan dilaksanakan dalam suatu negara. Sementara itu, negara tempat bertemunya peraturan hukum dari para pembawa juga memiliki peraturan hukum perdata. Kalau terjadi peristiwa hukum perdata yang menyangkut orang-orang asing dalam suatu negara, perlu diperhatikan tempat kejadian peristiwa itu. Hal ini berarti bahwa hukum perdata nasional yang harus berperan untuk menyelesaikannya. Dengan demikian, hukum perdata nasional harus dianggap berlaku sebagai hukum perdata internasional. Jadi, hukum perdata internasional ialah peraturan hukum perdata nasional yang berusaha mengatur hubungan hukumperdata yang menyangkut unsur-unsur asing di dalamnya.

Arti hukum perdata internasional dititikberatkan kepada peranan hukum perdata nasionalnya yang diberlakukan untuk mengatur hubungan hukum. Hal itu karena ada unsurunsur asing. Berarti, belum ada peraturan hukum perdata khusus yang bersifat internasional. Maksudnya, sampai sekarang belum ada satu peraturan hukum perdata yang bercorak unifikasi bagi setiap orang dalam hubungan hukum internasional. Sementara itu, yang ada dan berlaku hanyalah hukum perdata nasional sebagai pengatur hubungan hukum perdata yang di dalamnya terdapat unsur-unsur asing. Jadi, hukum perdata internasional itu bersifat nasional.

Peraturan hukum perdata nasional yang mengatur hubungan keperdataan dan mengandung unsur-unsur asing itu bertujuan memenuhi rasa keadilan bagi setiap individu. Maksudnya, kalau terjadi peristiwa hukum perdata antara dua orang asing atau lebih,

\footnotetext{
${ }^{12}$ Soehino, Hukum Tata Negara Teknik Perundang-Undangan, Liberty, Yogyakarta, 1996, Cet. 2, hal.
} 131-132. 
hendaknya masing-masing pihak berkewajiban melepaskan sebagian atau seluruh aturan hukum yang melekat pada dirinya. Selanjutnya menyelesaikan sesuai peraturan hukum perdata yang berlaku di negara itu dalam memenuhi kebutuhan masyarakat dengan memperoleh rasa keadilaan dirinya.

Peraturan hukum yang menjadi sumber hukum dari hukum perdata internasional di Indonesia terdapat dalam Algemene Bepalingen van Wetgeving (B). Asasnya dicantumkan dalam Pasal 16, 17, dan 18. Pasal 16 AB menyatakan bahwa: "Ketentuan-ketetntuan perundangan tentang kedudukan hukum dan kewenangan individu bertindak tetap mengikat warga Negara Indonesia walaupun berada diluar negeri”. Ketentuan pasal ini berpendirian: hukum Indonesia mengikuti warga negaranya. Berarti, mengenai kedudukan kewenangan hukum Indonesia selalu mengikuti warga Negara Indonesia di mana pun ia berada. Pendirian inilah yang kemudian disebut asas personal (lex rei sitae) atau statuta personalia. Bertitik tolak dari asas ini, maka bagi orang-orang asing yang berada di Indonesia mengenai kedudukan hukum dan kewenangannya harus ditinjau menurut hukumnya sendiri. Maksudnya, kalau ada orang asing hendak melakukan tindakan hukum perdata tertentu, harus ditinjau lebih dahulu hukum perdata yang berlaku di Indonesia.

Pasal 17 AB menyatakan bahwa: "Mengenai benda tetap (tidak bergerak) berlaku hukum dari negara tempat benda itu terletak". Ketentuan pasal ini merupakan suatu kaidah hukum setempat. Hal itu disebabkan kalau terjadi suatu peristiwa hukum perdata yang menyangkut tentang tanah sebagai benda tetap dan terletak di salah satu wilayah Indonesia, hukum yang digunakan adalah peraturan hukum Agraria Indonesia. Asas dari Pasal 17 AB dikenal sebagai asas hukum setempat (lex situs) yang disebut juga statuta realita. Pasal 18 $\mathrm{AB}$ menyatakan bahwa: "bentuk suatu tindakan hukum mengikuti bentuk hukum yang ditentukan oleh hukum negara atau tempat dilakukannya tindakan itu". Ketentuan pasal ini menunjuk kepada aturan hukum yang berlaku di tempat terjadinya peristiwa hukum yang menyangkut dua corak hukum yang berlainan. Jadi, kalau dalam suatu peristiwa hukum bertemu dua corak hukum yang berlainan di dalam suatu wilayah tertentu, aturan hukum tempat itulah yang berlaku. Asas dari pasal $18 \mathrm{AB}$ ini dikenal sebagai asas locus regit actus yang disebut juga statuta mixta. Ketiga asas hukum yang dicantumkan dalam Pasal 16, 17, dan $18 \mathrm{AB}$ ini sampai sekarang masih digunakan sebagai kaidah hukum perdata internasional di Indonesia yang utama dalam masalah keperdataan (hukum perdata materiil). Maksudnya, kalau terjadi peristiwa hukum berkenaan dengan hukum pribadi, hukum keluarga, hukum kekayaan, dan hukum waris yang menyangkut unsur- unsur asing di Indonesia, untuk menyelesaikannya terlebih dahulu dikembalikan kepada ketetuan-ketentuan Pasal 16, 17, dan $18 \mathrm{AB}^{13}$

Dengan demikian setiap peristiwa hukum yang terjadi dan menyangkut unsur-unsur asing di dalamnya, seperti orang asing yang akan menikah berpedoman pada Pasal 18 AB. Sementara itu, pelaksanaan penyelesaian perkawinan itu sampai terbentuk satu kesatuan keluarga diatur sepenuhnya dalam UU No. 1 Tahun 1974. Jadi, tidak ada suatu halangan apa pun yang dapat membatalkan suatu perkawinan kalau menaati peraturan hukum yang berlaku

${ }^{13}$ R. Abdoel Djamali, Pengantar Hukum Indonesia, Rajawali Pers, Jakarta, 2016, Cet. 21, hal. 228- 
di Indonesia. Hal tersebut menegaskan apa yang diamanatkan tentang perkawinan campuran yang diatur dalam UU No. 1 Tahun 1974.

\section{PENUTUP}

Dari berbagai uraian dan anaslisis terhadap taraf sinkronisasi vertical izin poligami bagi warga Negara asing, maka dapat ditarik beberapa kesimpulan sebagai berikut: Pernikahan poligami sudah berjalan sejak lama sesuai dengan perkembangan pergaulan manusia yang mendapat legalitas dari agama dan kebiasaan masing-masing. Peraturan perundang-undangan yang mengatur tentang izin poligami bagi warga Negara Indonesia sudah sesuai dengan aturan yang ada. Peraturan perundang-undangan yang mengatur tentang izin poligami bagi warga Negara asing tidak sinkron dan bertentangn dengan peraturan yang lebih tinggi.

\section{DAFTAR PUSTAKA}

\section{Buku}

Attamimi, Hamid S. 1990. Peranan Keputusan Presiden Republik Indonesia Dalam Penyelenggaraan Negara, Suatu Studi Analisis Mengenai Keputusan Presiden Yang Berfungsi Pengaturan dalam Kurun Waktu Pelita I-Pelita IV, Fakultas Pascasarjana UI, Jakarta.

Al San’ani, 1960, Subul al Salam, Dar Ihya' al Turas al ‘Araby, Juz. 3, Kairo.

Ahmad Rofiq, Haji, 2013, Hukum Perdata Islam Di Indonesia, Rajawali Pers, Cet. 1, Jakarta.

Bagir Manan, 2000, Teori dan Politik Konstitusi, Dirjen Dikti Depdiknas, Jakarta. Fadjar, A. Mukthie, 2004, Tipe Negara Hukum, Bayumedia, Cet. 1, Malang.

Vollmar, H. F. A, 1983, Inleiding tot de Studievan het Nederlands Burgerlijk Recht, (Pengantar Studi Hukum Perdata, terjemah oleh I. S. Adiwimarta, CV Rajawali, Cet. 1, Jakarta.

HS, Salim, 2005, Pengantar Hukum Perdata Tertulis (BW), Sinar Grafika, Cet. 3,Jakarta.

Jamali, R. Abdul, 2016, Pengantar Hukum Indonesia, Rajawali Pers, Cet. 21, Jakarta.

Martosoewignyo, Sri Soemantri, 1987, Prosedur dan Sistem Perubahan Konstitusi, Alumni, Cet. 4, Bandung.

Mertokusumo, Sudikno, 2001, Penemuan Hukum Sebuah Pengantar, Liberty, Cet. 2, Yogyakarta.

Maria Farida Indrati Soeprapto, 1998, Ilmu Perundang-Undangan Dasar-Dasar dan Pembentukannya, Kanisius, Yogyakarta.

Mustafa, Bachsan, 2003, Sistem Hukum Indonesia Terpadu, Citra Aditya Bakti,Bandung. 
233 Mamba'ul 'Ulum, Vol. 15, No. 2, Oktober 2019: 225-233

Soehino, 1996, Hukum Tatanegara Teknik Perundang-undangan, Liberty, Cet. 2, Yogyakarta.

Sumali, 2002, Reduksi Kekuasaan Eksekutif Di Bidang Peraturan Pengganti UndangUndang (PERPU), UMM Pres, Cet. 1, Malang.

Soekanto, Soerjono, 1986, Pengantar Penelitian Hukum, UI Press, Cet. 3, Jakarta. Sumardjono, Maria SW. , 2001, Pedoman Pembuatan Usulan Penelitian Sebuah Panduan Dasar, PT Gramedia Pustaka Utama, Cet. 3, Jakarta.

Soekanto, Soerjono dan Mamudji, Sri, 1985, Penelitian Hukum Normatif Suatu Tinjauan Singkat, CV Raajawali, Jakarta.

Sunggono, Bambang, 2005, Metodologi Penelitian Hukum, PT RajaGrafindo Persada, Cet. 7, Jakarta.

Sumitro, Ronny Hanitiyo, 1988, Metodologi Penelitian Hukum Dan Jurimetri, Ghalia Indonesia, Cet. 3, Jakarta.

Titik Triwulan Tutik dan Trianto, 2007, Poligami Perspektif Perikatan Nikah Telaah Kontekstual Menurut Hukum Islam dan Undang-undang Perkawinan No. 1 Tahu 1974, Prestasi Pustakaraya, Cet. 1, Jakarta.

\section{Peraturan Perundang-Undangan}

Republik Indonesia, Undang-Undang No. 1 Tahun 1974 Tentang Perkawinan Republik Indonesia, Undang-Undang No. 10 Tahun 2004 Tentang Pembentukan Peraturan Perundang-undangan

Republik Indonesia, Peraturan Pemerintah No. 9 Tahun 1975 Tentang Pelaksanaan Undang-Undang No. 1 Tahun 1974 Tentang Perkawinan

Republik Indonesia, Inpres No. 1 Tahun 1991 Tentang Kompilasi Hukum Islam Republik Indonesia, Ketetapan MPR No. III Tahun 2000 Tentang Sumber Hukum dan Tata Urutan Peraturan Perundang-Udangan

Peraturan Menteri Agama No. 19 Tahun 2018 Tentang Pencatatan Perkawinan

\section{Kamus, Ensiklopedi}

Sudarsono, 2002, Kamus Hukum, Rieneka Cipta, Cet. 3, Jakarta. Ensiklopedi Idonesia, W Van Hoeve. 